\title{
СОСТАВ И СОДЕРЖАНИЕ АНТОЦИАНОВ В ДИЕТИЧЕСКИХ СОРТАХ КАРТОФЕЛЯ (Solanum tuberosum L.), ПЕРСПЕКТИВНЫХ ДЛЯ ВЫРАЩИВАНИЯ И СЕЛЕКЦИИ В УСЛОВИЯХ ДАЛЬНЕГО ВОСТОКА РОССИИ*
}

\author{
И.В. КИМ ${ }^{凶}$, Д.И. ВОЛКОВ1, В.М. ЗАХАРЕНКО², А.М. ЗАХАРЕНКО 2 , \\ К.С. ГОЛОХВАСТ ${ }^{2}$, А.Г. КЛЫКОВ 1
}

В последние десятилетия большое внимание уделяется наличию фенольных веществ (антоцианов) в картофеле (Solanum tuberosum L.), поскольку эта культура рассматривается как продукт для диетического питания. В России такие сорта созданы для ряда регионов возделывания, но в условиях Дальнего Востока работы по увеличению содержания антоцианов в клубнях картофеля начаты недавно. В представленном исследовании с применением методов жидкостной хроматографии и масс-спектрометрии второго порядка мы идентифицировали антоцианы и измерили их содержание у сортов картофеля разного происхождения (Россия, Украина, Беларусь, Казахстан, Германия, Нидерланды), которые ранее не были охарактеризованы по этому признаку. Впервые выделены четыре сорта российского происхождения с повышенным содержанием антоцианов для диетического использования. Целью работы было определение профилей антоцианов и их содержания в клубнях в условиях российского Дальнего Востока. В качестве материала использовали 22 сорта, отобранных по раннеспелости, продуктивности, с низким содержанием крахмала, разной окраской клубней и венчика соцветия. Антоциановые профили анализировали методом двойной идентификации: по времени удерживания на обратнофазной колонке С18 с детектированием в диапазоне длин волн 400-700 нм и методом масс-спектрометрии второго порядка в режиме положительной ионизации с последующей фрагментацией ионов. В клубнях изученных сортообразцов выявлены дельфинидин, петунидин, мальвидин, цианидин и пеларгонидин. Дельфинин и цианидин обнаружены в двух формах - в моно- и дигликозилированной. Наиболее распространенным антоцианом оказался петунидин-3-глюкозид, он присутствовал почти во всех исследованных образцах. Установлено, что антоциановый состав клубне изменяется в зависимости от сорта и может включать от одного до пяти антоцианов. Сорта с желтой окраской кожуры и розовыми пятнами на желтой кожуре клубня характеризовались незначительным содержанием антоциановых компонентов. Исследования показали, что розовая и темно-розовая окраска кожуры определяется содержанием в ней пеларгонидин-3-глюкозида. Петунидин-3-гликозид и цианидин-3-глюкозид придавали кожуре фиолетовую и сине-фиолетовую окраску. Среди исследованных сортов наибольшее содержание антоцианов отмечено в сортах Фиолетовый (цианидин-3-глюкозид - 310 мг/кг, мальвидин 50 мг/кг, дельфинидин - 30 мг/кг), Василек (петунидин-3-глюкозид - 150 мг/кг), Маяк (пеларгонидин - 95 мг/кг) и Кузнечанка (пеларгонидин -78 мг/кг). В селекции картофеля на повышенное содержание антоцианов рекомендуем использовать сорта с розовой, темно-розовой, фиолетовой и сине-фиолетовой кожурой.

Ключевые слова: Solanum tuberosum L., картофель, диетические сорта, антоцианы, дельфинидин, петунидин, мальвидин, цианидин, пеларгонидин, масс-спектрометрия, ВЭЖХ.

Картофель (Solanum tuberosum L., сем. Solanaceae) как продукт питания по важности занимает четвертое место после пшеницы, риса и кукурузы. Среди клубнеплодных и корнеплодных культур он первый по объемам выращивания (1). Пищевая значимость картофеля во многом обусловлена высоким содержанием углеводов, значительным количеством аскорбиновой кислоты, антоцианов, хорошей усвояемостью белков, солей калия, кальция, магния (2).

Антоциановые пигменты могут синтезироваться в кожуре и мякоти клубней картофеля. Кроме того, окрашенными могут быть цветки, листья, стебли и глазки. У картофеля как важной продовольственной культуры содержание антоцианов целесообразно повышать в съедобной части растения - мякоти клубней (3).

Антоциановые пигменты используются в пищевой и фармацевти-

\footnotetext{
* Исследования выполнены в рамках КПНИ развития сельского хозяйства РФ на 2017-2025 годы (подпрограмма «Развитие селекции и семеноводства картофеля в Российской Федерации»).
} 
ческой промышленности. Они относятся к водорастворимым природным красителям - антиоксидантам, способным окрашивать продукты питания в разные оттенки красного (альтернатива канцерогенному азокрасителю кармуазину) и рекомендованы российскими санитарными правилами и нормами для подкрашивания некоторых видов сыров, вин, безалкогольных напитков, консервированные овощей, сухих завтраков (до 200 мг/кг), джемов, желе, мармеладов $(4,5)$.

Известно, что антоцианы обладают капилляроукрепляющими, антиоксидантными, антибактериальными и антиканцерогенными свойствами и применяются в медицине для лечения и профилактики ряда заболеваний (например, сахарного диабета II типа и некоторых форм опухолей) (6-9).

Повышение эффективности селекции по признакам окраски мякоти клубня (красная и фиолетовая) связывают с разработкой ДНК маркеров целевых генов биосинтеза антоцианов на основе применения ПЦР-анализа. Известно, что в генетическом контроле биосинтеза антоцианов участвуют структурные гены ферментов халконсинтазы (CHS), халконфлаванонизомеразы (CHI), дигидрофлавонол-4-редуктазы (DFR), флавонон-3-гидроксилазы $(\mathrm{F} 3 \mathrm{H})$, флавоноид-3' -гидроксилазы (F3'H), флавоноид-3',5'-гидроксилазы (F3'5'H) и антоцианидинсинтазы (ANS) $(10,11)$. У $S$. tuberosum также обнаружены локусы, соответствующие регуляторным генам. Локус $D$ (developer, у диплоидного картофеля S. rybinii Juz. \& Bukasov обозначен как $I$ - inhibitor), расположенный в 10-й хромосоме, кодирует транскрипционный фактор (ТФ) R2R3 MYB, обладающий высоким сходством с продуктом ранее выделенного гена петунии (Petunia hybrid) - PhAN2 (12). Представители R2R3 MYB - самая большая группа генов, кодирующих ТФ у растений. Они выполняют важную роль в биосинтезе антоцианов (13-15).

Изученность генетики антоциановой пигментации клубней и цветков у селекционных форм $S$. tuberosum существенно облегчает подбор родительских пар для скрещивания и планирование объемов селекционного материала при отборе гибридов с окрашенными цветками, стеблями, листьями и клубнями (16-18).

Пигментированные сорта картофеля $S$. tuberosum богаты антоцианами, в частности их ацилированными производными (19). Генотипы картофеля сильно различаются по содержанию биологически активных соединений, в том числе антоцианов. Пигментированные сорта обладают в 1,52,5 раза большей фенольной активностью, в 2-3 раза большей антиоксидантной способностью и накапливают больше антоцианов, чем непигментированные генотипы. В непигментированном картофеле антоцианы не обнаружены (20).

В США селекционная работа по созданию специальных диетических сортов ведется с начала 2000 годов, в результате получены сорта с высоким содержанием каротиноидов и антоцианов, имеющие красную и фиолетовую мякоть клубней (4). В России также достигнуты значительные успехи в создании сортов картофеля для диетического питания, проводятся исследования по определению суммарного содержания антиоксидантов в сортообразцах картофеля, выделены сорта, которые имеют наибольший индекс пигментации и содержат в 5 раз больше антикосидантов, чем беломякотные сорта (21).

На Дальнем Востоке работы по увеличению содержания антоцианов в клубнях картофеля начаты в 2018 году. При оценке сортов различного происхождения (Россия, Нидерланды, Германия, Казахстан, Украина и Беларусь) выделены источники ценных хозяйственных признаков (повышенная урожайность, красная и фиолетовая окраска кожуры клубня, красно- 
фиолетовая окраска венчика), которые включены в скрещивания с целью получения диетических сортов (22). Для дальнейшей селекционной работы необходимо дополнительное изучение диетических антиоксидантных свойств у выделенных ранее сортов, анализ состава и содержания антоцианов в клубнях и сопоставление этих данных с наличием антоциановой окраски других органов (кожура и венчик цветка) у пигментированных сортов для выявления связи этих признаков.

В представленном исследовании с применением методов высокоэффективной жидкостной хроматографии (ВЭЖХ) и масс-спектрометрии второго порядка мы идентифицировали антоцианы и измерили их содержание у 22 сортов картофеля различного происхождения, которые ранее не были охарактеризованы по этому признаку. Впервые выделены четыре сорта российского происхождения с повышенным содержанием антоцианов для диетического использования.

Целью работы было определение состава и количественного содержания антоцианов в клубнях диетических сортов картофеля, перспективных для выращивания и селекции на Дальнем Востоке России.

Методика. Сорта картофеля (мировая коллекции ФИЦ Всероссийский институт генетических ресурсов растений им. Н.И. Вавилова - ВИР, г. Санкт-Петербург; коллекция Всероссийского НИИ картофельного хозяйства им. А.Г. Лорха, Московская обл.; сорта, полученные в ФНЦ агробиотехнологий Дальнего Востока им. А.К. Чайки) изучали в коллекционном питомнике (ФНЦ агробиотехнологий Дальнего Востока им. А.К. Чайки, 20162018 годы). По признакам раннеспелости (продуктивность 440-650 г/куст на 60-е и 70-е сут после посадки) и окраске клубней была сформирована выборка из 22 сортов: Башкирский, Василек, Дачный, Казачок, Крепыш, Кузнечанка, Матушка, Маяк, Метеор, Огниво, Ольский, Памяти Кулакова, Сарма, Сиреневый туман, Фиолетовый, Янтарь (Россия), Sante (Сантэ) (Нидерланды), Vitesse (Германия), Тамыр (Казахстан), Повінь, Щедрик (Украина), Манифест (Беларусь).

Состав и накопление антоцианов анализировали по методу C.E. Lewis с соавт. (20). Для определения содержания антоцианов использовали ткани мякоти клубней (вместе с кожурой). Собранные образцы хранили до начала анализа (не более 2 нед) в прохладном месте без доступа прямых солнечных лучей. Образцы промывали в холодной воде, взвешивали, измельчали и заливали раствором, содержащим $40 \%$ этилового спирта и $1 \%$ муравьиной кислоты (5 г измельченной массы +25 мл полученного раствора). Массу подвергали замораживанию-размораживанию, а также ультразвуковой дезинтеграции для разрушения стенок и мембран клеток и органелл. Атоцианы экстрагировали в течение 90 мин при $40{ }^{\circ} \mathrm{C}$ в закрытом сосуде для предотвращения доступа атмосферного кислорода. Экстракт центрифугировали (CM-6M, «Elmi», Латвия) при 3500 g в течение 30 мин, супернатант фильтровали через шприцевые фильтры (размер пор 0,45 мкм). Готовый экстракт хранили в морозильной камере при температуре $-20{ }^{\circ} \mathrm{C}$.

Антоцианы разделяли методом ВЭЖХ на жидкостном хроматографе с градиентным насосом высокого давления LC-20AD и блоком термостатирования колонок CTO-20A («Shimadzu», Япония). Хроматографию проводили на обратнофазной колонке Shodex C18-4E (250×4,6 мм), диаметр зерна сорбента - 5 мкм («Shodex», Япония), температура $50{ }^{\circ} \mathrm{C}$, скорость подвижной фазы составляла 0,58 мл/мин. Элюент А - ацетонитрил («AppliChem $\mathrm{GmbH»,} \mathrm{Германия),} \mathrm{элюент} \mathrm{B}-1 \%$ раствор муравьиной кислоты («SigmaAldrich», США). Градиент: 0,00-5,00 мин - концентрация В изменялась от $100 \%$ до $92 \%$; 5,00-45,00 мин - концентрация В изменялась от $92 \%$ до 
$80 \%$; 45,00-45,01 мин - концентрация В изменялась от $80 \%$ до $10 \%$. Детектирование проводили в диапазоне длин волн 300-600 нм UV/VIS спектрофотометрическим детектором SPD-20A («Shimadzu», Япония). Для анализа вводили по 5 мкл экстракта. Анализ проводили в 66 биологических и 3 аналитических повторностях. Для сортов Фиолетовый и Василек содержание антоцианов пересчитывали по мальвидин-3-глюкозиду, используя коэффициент поглощения $3,02 \times 10^{4}$ в диапазоне длин волн 300-600 нм и молекулярную массу 493,3 г/моль, для остальных сортов - по пеларгонидин-3-глюкозиду с молярным коэффициентом экстинкции 2,73×104 при диапазоне длин волн 300-600 нм и молекулярной массой 433, 3 г/моль.

Антоцианы идентифицировали методами масс-спектрометрии второго порядка с помощью ловушки amaZon SL («Bruker», Германия), оснащенной источником ионизации электрораспылением. Для этого выделенные ранее методом ВЭЖХ антоцианины анализировали методом прямого ввода. Детектирование проводили в режиме положительных и отрицательных ионов. Диапазон сканирования масс - от 150 до 2200 а.е.м., максимальная скорость сканирования 32000 Да/с, напряжение на распыляющем капилляре 4500 В, давление на небулайзере 29 psi, поток сухого газа 10 л/с, температура капилляра $180{ }^{\circ} \mathrm{C}$. Фрагментацию ионов проводили электронным пучком с энергией 1,5 эВ. Анализ проводили в 66 биологических и 3 аналитических повторностях.

Для проверки достоверности полученных результатов использовали статистические программы MS Excel 2007 и Statistica 8 («StatSoft, Inc.», США), рассчитывали средние $(M)$ и t0,05 $\times$ SEM.

Результаты. Выделенная группа сортов характеризовалась низкой крахмалистостью (8,0-12,0 \%) и имела розовую и фиолетовую окраску кожуры. Известно, что низкокрахмалистые образцы относятся к группе сортов для диетического использования (23).

Антоциановая окраска разных частей растений - важный признак, который можно эффективно использовать в селекции на повышенное содержание пигментных веществ фенольной природы (5). Изученные нами сорта различались по морфологическим признакам клубней (табл. 1).

1. Морфологические признаки изученных сортов картофеля (Solanum tuberosum L.) (коллекционный питомник ФНЦ агробиотехнологий Дальнего Востока им. А.К. Чайки, 2016-2017 годы)

\begin{tabular}{|c|c|c|c|}
\hline \multirow{2}{*}{ Сорт } & \multicolumn{3}{|c|}{ Окраска } \\
\hline & мякоти клубня & венчика соцветия & кожуры клубня \\
\hline $\begin{array}{l}\text { Sante, Казачок, Vitesse, } \\
\text { Сарма, Метеор }\end{array}$ & Желтая & Белая & Желтая \\
\hline Крепыш & Белая & Бледно-красно-фиолетовая с белым лучом & \\
\hline Дачный, Щедрик & Белая & Белая & \\
\hline Янтарь & Ярко-желтая & Белая & \\
\hline Тамыр & Светло-желтая & Белая & \\
\hline Ольский & Кремовая & Белая & Желтая с розо- \\
\hline Памяти Кулакова & Белая & Белая & выми пятнами \\
\hline Кузнечанка, Башкирский & Белая & Бледно-красно-фиолетовая & Розовая \\
\hline Сиреневый туман & Светло-желтая & Бледно-красно-фиолетовая с белым лучом & \\
\hline Повінь & Желтая & Бледно-красно-фиолетовая & \\
\hline Матушка & Кремовая & Белая & \\
\hline Огниво & Кремовая & Красно-фиолетовая с белым лучом & \\
\hline Маяк & Кремовая & Бледно-красно-фиолетовая & Темно-розовая \\
\hline Манифест & Кремовая & Красно-фиолетовая с белым лучом & \\
\hline Василек & Кремовая & Сине-фиолетовый с белым лучом & Фиолетовая \\
\hline Фиолетовый & Фиолетовая & Сине-фиолетовая с белым лучом & Сине-фиолетовая \\
\hline
\end{tabular}

Пять образцов картофеля (Казачок, Метеор, Сарма, Sante, Vitesse) характеризовались белой окраской венчика соцветия, но желтой кожурой и мякотью. У остальных сортов пигментация частей растений была неоди- 
наковой (желтая, оттенки красно-фиолетового, фиолетовая, розовая и т.д.). Морфологические признаки, отмеченные в наших исследованиях (окраска генеративных органов и кожуры клубней в период цветения), соответствуют известным описаниям (24).

В результате определения антоцианового профиля в клубнях было выявлено пять различных антоцианов (табл. 2). Масс-спектрометрия второго порядка идентифицировала выделенные антоцианы как дельфинидин, петунидин, мальвидин, цианидин и пеларгонидин. Согласно данным литературным, биохимическая природа антоцианов у $S$. tuberosum такая же, как у культурных диплоидных видов (25). В состав их антоцианов входят пеларгонидин, пеонидин, петунидин и мальвидин.

2. Антоциановый профиль клубней у изученных сортов картофеля (Solanum tuberosum L.) по данным высокоэффективной жидкостной хроматографии и МC-MC масс-спектрометрии (коллекционный питомник ФНЦ агробиотехнологий Дальнего Востока им. А.К. Чайки, 2018 год)

\begin{tabular}{|c|c|c|c|}
\hline Антоциан & $\begin{array}{l}\text { Молекулярный ион } \\
{[\mathrm{M}+\mathrm{H}]^{+}}\end{array}$ & $\begin{array}{l}\text { Время выхода } \\
\text { на ВЭЖХ, мин }\end{array}$ & Сорт \\
\hline Дельфинин-3-глюкозид & 465,$3 ; 303,2$ & 25 & $\begin{array}{l}\text { Маяк, Повінь, Кузнечанка, Мани- } \\
\text { фест, Фиолетовый }\end{array}$ \\
\hline $\begin{array}{l}\text { Дельфинин-3-рамнозил-5- } \\
\text { глюкозид }\end{array}$ & 627,$3 ; 465,3 ; 303,2$ & 17,5 & $\begin{array}{l}\text { Маяк, Повінь, Кузнечанка, Василек, } \\
\text { Манифест }\end{array}$ \\
\hline Мальвидин-3-глюкозид & 493,$3 ; 331,3$ & 44 & Фиолетовый \\
\hline Пеларгонидин-3-глюкозид & 433,$3 ; 271,1$ & 37,5 & $\begin{array}{l}\text { Маяк, Повінь, Кузнечанка, Фиолето- } \\
\text { вый, Василек }\end{array}$ \\
\hline Петунидин-3-глюкозид & 479,$3 ; 317,2$ & 35 & $\begin{array}{l}\text { Василек, Манифест, Матушка, Повінь } \\
\text { Мали, Сиреневый туман, Памяти Ку- } \\
\text { лакова, Ольский }\end{array}$ \\
\hline Цианидин-3-глюкозид & 449,$2 ; 287,2$ & 27,5 & Фиолетовый \\
\hline $\begin{array}{l}\text { Цианидин-3-рамнозил-5- } \\
\text { глюкозид }\end{array}$ & 611,$3 ; 499,3 ; 287,2$ & 19 & $\begin{array}{l}\text { Матушка, Василек, Фиолетовый, } \\
\text { Повінь }\end{array}$ \\
\hline
\end{tabular}

3. Содержание (мг/кг) антоцианов в клубнях у изученных сортов картофеля (Solanum tuberosum L.) $(n=3, M \pm t 0,05 \times \mathrm{SEM}$, коллекционный питомник ФНЦ агробиотехнологий Дальнего Востока им. А.К. Чайки, 2018 год)

\begin{tabular}{|c|c|c|c|c|c|c|c|}
\hline Copт & 1 & 2 & 3 & 4 & 5 & 6 & 7 \\
\hline \multicolumn{8}{|c|}{ 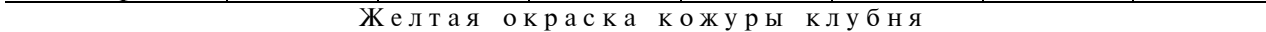 } \\
\hline Sante & $<0,5$ & $<0,5$ & $1,0 \pm 0,1$ & $<0,5$ & $<0,5$ & $<0,5$ & $<0,5$ \\
\hline Казачок & $<0,5$ & $<0,5$ & $<0,5$ & $<0,5$ & $2,1 \pm 0,1$ & $<0,5$ & $<0,5$ \\
\hline Vitessa & $<0,5$ & $<0,5$ & $<0,5$ & $0,9 \pm 0,1$ & $<0,5$ & $<0,5$ & $<0,5$ \\
\hline Сарма & $<0,5$ & $<0,5$ & $<0,5$ & $2,2 \pm 0,1$ & $<0,5$ & $<0,5$ & $<0,5$ \\
\hline Метеор & $<0,5$ & $<0,5$ & $1,1 \pm 0,1$ & $1,8 \pm 0,1$ & $<0,5$ & $<0,5$ & $<0,5$ \\
\hline Дачный & $<0,5$ & $<0,5$ & $1,0 \pm 0,1$ & $<0,5$ & $<0,5$ & $<0,5$ & $<0,5$ \\
\hline Щедрик & $<0,5$ & $<0,5$ & $<0,5$ & $<0,5$ & $<0,5$ & $<0,5$ & $<0,5$ \\
\hline Янтарь & $<0,5$ & $<0,5$ & $<0,5$ & $<0,5$ & $1,8 \pm 0,1$ & $<0,5$ & $<0,5$ \\
\hline Тамыр & $<0,5$ & $<0,5$ & $<0,5$ & $<0,5$ & $2,0 \pm 0,1$ & $<0,5$ & $<0,5$ \\
\hline Крепыш & $<0,5$ & $<0,5$ & $<0,5$ & $1,2 \pm 0,1$ & $<0,5$ & $<0,5$ & $<0,5$ \\
\hline \multicolumn{8}{|c|}{ у бня с розовым и п } \\
\hline Ольский & $<0,5$ & $<0,5$ & $<0,5$ & $5,3 \pm 0,1$ & $<0,5$ & $<0,5$ & $<0,5$ \\
\hline Памяти Кулакова & $<0,5$ & $<0,5$ & $<0,5$ & $3,2 \pm 0,1$ & $<0,5$ & $<0,5$ & $<0,5$ \\
\hline \multicolumn{8}{|c|}{ Розовая окраска кожуры клубня } \\
\hline Кузнечанка & $4,1 \pm 0,1$ & $9,7 \pm 0,1$ & $<0,5$ & $78,4 \pm 0,3$ & $<0,5$ & $<0,5$ & $<0,5$ \\
\hline Башкирский & $0,9 \pm 0,1$ & $3,1 \pm 0,1$ & $<0,5$ & $24,8 \pm 0,2$ & $2,3 \pm 0,1$ & $<0,5$ & $<0,5$ \\
\hline Сиреневый туман & $2,7 \pm 0,1$ & $<0,5$ & $12,1 \pm 0,1$ & $5,0 \pm 0,1$ & $<0,5$ & $<0,5$ & $<0,5$ \\
\hline Повінь & $3,0 \pm 0,1$ & $7,3 \pm 0,1$ & $<0,5$ & $24,8 \pm 0,2$ & $5,0 \pm 0,1$ & $<0,5$ & $10,2 \pm 0,1$ \\
\hline Матушка & $<0,5$ & $1,1 \pm 0,1$ & $<0,5$ & $22,2 \pm 0,2$ & $0,7 \pm 0,1$ & $<0,5$ & $<0,5$ \\
\hline Огниво & $1,3 \pm 0,1$ & $<0,5$ & $<0,5$ & $1,9 \pm 0,1$ & $<0,5$ & $<0,5$ & $<0,5$ \\
\hline \multicolumn{8}{|c|}{ Темно-розовая окраска кожуры клубня } \\
\hline Маяк & $2,1 \pm 0,1$ & $2,1 \pm 0,1$ & $<0,5$ & $94,6 \pm 0,3$ & $9,9 \pm 0,1$ & $<0,5$ & $<0,5$ \\
\hline Манифест & $1,0 \pm 0,1$ & $1,2 \pm 0,1$ & $<0,5$ & $20,1 \pm 0,2$ & $1,1 \pm 0,1$ & $<0,5$ & $<0,5$ \\
\hline \multicolumn{8}{|c|}{ окраска кожуры клубня } \\
\hline Василек & $<0,5$ & $5,0 \pm 0,1$ & $<0,5$ & $38,2 \pm 0,2$ & $149,8 \pm 0,4$ & $<0,5$ & $2,0 \pm 0,1$ \\
\hline \multicolumn{8}{|c|}{ Сине - фиолетовая окраска кожуры клубня } \\
\hline Фиолетовый & $30,4 \pm 0,2$ & $<0,5$ & $50,1 \pm 0,2$ & $<0,5$ & $5,1 \pm 0,1$ & $310,0 \pm 0,4$ & $8,4 \pm 0,1$ \\
\hline
\end{tabular}


Антоцианы дельфинин и цианидин обнаружили как в моногликозилированной, так и в дигликозилированной форме. Наиболее распространенными антоцианами в образцах были петунидин-3-глюкозид и пеларгонидин-3-глюкозид: их идентифицировали практически во всех исследованных образцах (табл. 3).

По данным литературы, петунидин и пеларгонидин - это основные антоцианы, встречающиеся в картофеле. Петунидин обусловливает пурпурную окраску, а пеларгонидин - красно-оранжевую $(20,26)$. При исследовании сортов с розовой и темно-розовой окраской клубня мы выявили превалирующее присутствие пеларгонидин-3-глюкозида, сорта с фиолетовой и сине-фиолетовой окраской содержали преимущественно петунидин-3-глюкозид. В образцах с желтой окраской кожуры антоциановые вещества детектировали либо в незначительном количестве, либо их не обнаружили.

Наибольшее содержание антоцианов было характерно для сортов Фиолетовый, Василек, Маяк и Кузнечанка. Сорт Фиолетовый, у которого кожура и мякоть клубня сине-фиолетовые, выделялся значительным содержанием четырех антоцианов - цианидин-3-глюкозида (310 мг/кг), мальвидина (50 мг/кг), дельфинидина (30 мг/кг) и цианидин-3-рамнозил5-глюкозида (8 мг/кг). Сорта Маяк и Кузнечанка имели розовые и темнорозовые клубни и выделились повышенным содержанием пеларгонидина соответственно 95 и 78 мг/кг. Сорт Василек с фиолетовой кожурой клубней характеризовался самым высоким содержанием петунидин-3-глюкозида 150 мг/кг. Выделенные сорта могут быть использованы в качестве функционального продукта питания с высокими антиоксидантными свойствами.

В клубнях сорта Фиолетовый цианидин-3-глюкозид оказался основным компонентом (рис.).

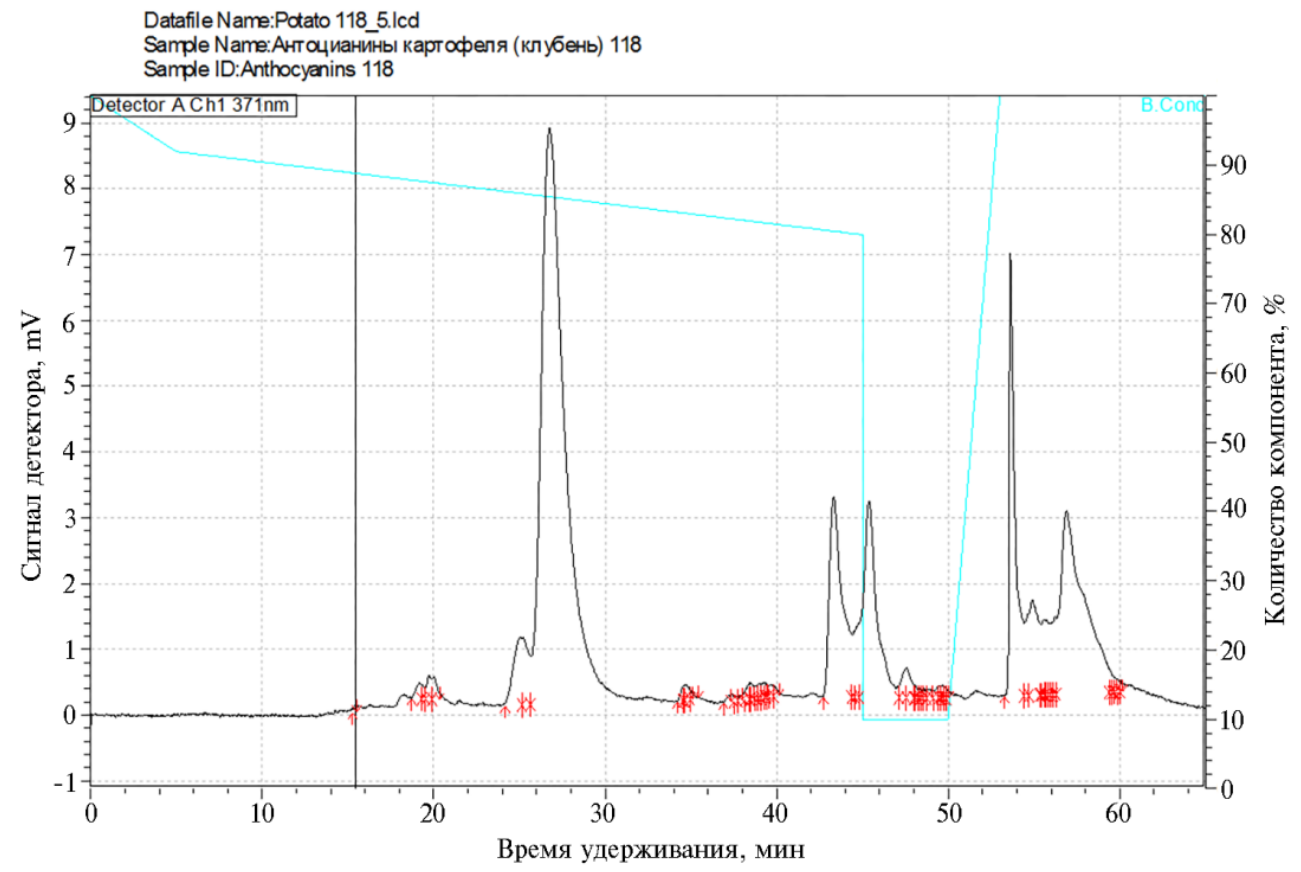

Профиль элюции антоцианов, выделенных из клубней картофеля (Solanum tuberosum L.) copта Фиолетовый $(n=3$, коллекционный питомник ФНЦ агробиотехнологий Дальнего Востока им. А.К. Чайки, 2018 год). Метод ВЭЖХ, обратнофазная колонка Shodex C18-4E (250×4,6 мм), элюент A - ацетонитрил («AppliChem $\mathrm{GmbH»,} \mathrm{Германия),} \mathrm{элюент} \mathrm{В} \mathrm{-} 1 \%$ раствор муравьиной кислоты («Sigma-Aldrich», США). Градиент: 0,00-5,00 мин. Пик цианидин-3-глюкозид - 27,5 мин, мальвидин-3-глюкозида -44 мин, дельфинин-3-глюкозида -25 мин. 
Наиболее интенсивный сигнал (при длине волны 371 нм) (время удерживания 27,5 мин) соответствует основному антоциану этого сорта цианидин-3-глюкозиду, кроме того, присутствуют в значительных количествах мальвидин-3-глюкозид (пик при 44 мин) и дельфинин-3-глюкозид (небольшой пик при 25 мин). Профили элюции выявили связь между содержанием конкретных антоцианов и окраской клубней, а также их принадлежностью к определенному сорту. Имеющиеся публикации подтверждают, что качественный состав антоцианов, как правило, специфичен для конкретного вида растений и довольно стабилен. Однако он зависит от сортовых особенностей и условий произрастания растений, которыми определяется активность соответствующих ферментов, способствующих синтезу определенных компонентов антоцианового комплекса $(19,27)$.

Сорта с фиолетовой и розовой кожурой разных оттенков выделились по содержанию антоцианов в клубнях по сравнению с сортообразцами с желтыми клубнями. Следовательно, окраска кожуры клубня (розовая, темно-розовая, сине-фиолетовая, фиолетовая) может использоваться в качестве визуального признака в селекции при создании диетических сортов с повышенным содержанием антоцианов.

Итак, в результате проведения масс-спектрометрии второго порядка в клубнях сортов картофеля при определении антоцианов идентифицированы дельфинидин, петунидин, мальвидин, цианидин и пеларгонидин. Наиболее распространен петунидин-3-глюкозид - его обнаружили практически во всех исследованных образцах. Наибольшее содержание антоцианов отмечено в сортах Фиолетовый, Василек, Маяк и Кузнечанка. Сорт Фиолетовый с сине-фиолетовой кожурой и мякотью клубня выделился значительным содержанием четырех антоцианов - дельфинидина (30 мг/кг), мальвидина (50 мг/кг), цианидин-3-глюкозида (310 мг/кг) и цианидин-3рамнозил-5-глюкозида (8 мг/кг). Сорта Маяк и Кузнечанка имели клубни розовой и темно-розовой окраски и выделились повышенным содержанием пеларгонидина - соответственно 95 и 78 мг/кг. Сорт Василек с фиолетовой кожурой клубней характеризовался самым высоким содержанием петунидин-3-глюкозида - 150 мг/кг. Полученные результаты показали, что окраска кожуры клубня может использоваться в качестве признака при отборе и создании сортов с повышенным содержанием антоцианов. Установлено, что для клубней с розовой и темно-розовой кожурой характерно наличие пеларгонидин-3-глюкозида. Петунидин-3-глюкозид и цианидин-3-глюкозид придают кожуре фиолетовую и сине-фиолетовую окраску. Выделенные сортообразцы картофеля диетического направления включены в селекционные программы по созданию диетических сортов. Для этого мы планируем далее изучить наследуемость желаемой антоциановой пигментации в создаваемых сортах картофеля и определить наборы генов, отвечающих за состав и содержание антоцианов в клубнях.

\section{Л ИТ Е РАТУРА}

1. Жевора С.В., Анисимов Б.В., Симаков Е.А., Овэс Е.В., Зебрин С.Н. Картофель: проблемы и перспективы. Картофель и овощи, 2019, 7: 2-7.

2. Иванисенко Т.В., Сайк О.В., Деменков П.С., Хлесткин В.К., Хлесткина Е.К., Колчанов Н.А., Иванисенко В.А. База знаний SOLANUM TUBEROSUM: раздел по молекулярно-генетической регуляции метаболических путей. Вавиловский журнал генетики и селекции, 2018, 22(1): 8-17 (doi: 10.18699/VJ18.325).

3. Zhang Y., Cheng S., De Jong D., Griffiths H., Halitschke R., De Jong W. The potato $R$ locus codes for dihydroflavonol 4-reductase. Theor. Appl. Genet., 2009, 119(5): 931-937 (doi: 10.1007/s00122-009-1100-8).

4. Wegener C.B., Jansen G. Soft-rot resistance of coloured potato cultivars (Solanum tuberosum L.): 
the role of anthocyanins. Potato Res., 2007, 50(1): 31-44 (doi: 10.1007/s11540-007-9027-4).

5. Симаков Е.А., Анисимов Б.В., Митюшкин А.В., Жевора С.В., Старовойтов В.И., Овэс Е.В., Журавлев А.А., Мелешин А.А., Зебрин С.Н., Зейрук В.Н., Усков А.И., Жарова В.А., Митюшкин Ал.Р.В., Шабанов А.Э., Мальцев С.В., Салюков С.С., Овечкин С.В., Семенов В.А., Гайзатулин А.С. Сорта картофеля селекционного центра ВНИИКХ. Потребительские и столовые качества, кулинарный тип. М., 2016.

6. Mulinacci N., Ieri F., Giaccherini C., Innocenti M., Andrenelli L., Canova G., Saracchi M., Casiraghi M.C. Effect of cooking on the anthocyanins, phenolic acids, glycoalkaloids, and resistant starch content in two pigmented cultivars of Solanum tuberosum L. J. Agric. Food Chem., 2008, 56(24): 11830-11837 (doi: 10.1021/jf801521e).

7. Cassidy A., O’Reilly È.J., Kay C., Sampson L., Franz M., Forman J.P., Curhan G., Rimm E.B. Habitual intake of flavonoid subclasses and incident hypertension in adults. The American Journal of Clinical Nutrition, 2011, 93(2): 338-347 (doi: 10.3945/ajcn.110.006783).

8. Hui C., Bi Y., Xiaopin Y., Lon Y., Chunye C., Mantian M., Wenhua L. Anticancer activities of an anthocyanin-rich extract from black rice against breast cancer cells in vitro and in vivo. $\mathrm{Nu}$ trition and Cancer, 2010, 62(8): 1128-1136 (doi: 10.1080/01635581.2010.494821).

9. Sancho R.A.S., Pastore G.M. Evaluation of the effects of anthocyanins in type 2 diabetes. Food Research International, 2012, 46(1): 378-386 (doi: 10.1016/j.foodres.2011.11.021).

10. Стрыгина К.В., Хлесткина Е.К. Синтез антоцианов у картофеля (Solanum tuberosum L.): генетические маркеры для направленного отбора. Сельскохозяйственная биология, 2017, 52(1): 37-49 (doi: 10.15389/agrobiology.2017.1.25rus).

11. Zhang Y., Jung C.S., De Jong W.S. Genetic analysis of pigmented tuber flesh in potato. Theor. Appl. Genet., 2009, 119(1): 143-150 (doi: 10.1007/s00122-009-1024-3).

12. Stushnoff C., Ducreux L.J., Hancock R.D., Hedley P.E., Holm D.G., McDougall G.J., McNicol J.W., Morris W. L., Sugurtas J.A., Verrall S.R., Zuber T., Taylor M.A. Flavonoid profiling and transcriptome analysis reveals new gene-metabolite correlations in tubers of Solanum tuberosum L. Journal of Experimental Botany, 2010, 61(4): 1225-1238 (doi: 10.1093/jxb/erp394).

13. Feller A., Machemer K., Braun E.L., Grotewold E. Evolutionary and comparative analysis of MYB and bHLH plant transcription factors. Plant J., 2011, 66(1): 94-116 (doi: 10.1111/j.1365313X.2010.04459.x).

14. Allan A.C., Hellens R.P., Laing W.A. MYB transcription factors that colour our fruit. Trends in Plant Science, 2008, 13(3): 99-102 (doi: 10.1016/j.tplants.2007.11.012).

15. Dubos C., Stracke R., Groteworld E., Weisshar B., Martin C., Lepiniec L. MYB transcription factors in Arabidopsis. Trends in Plant Science, 2010, 15(10): 573-581 (doi: 10.1016/j.tplants.2010.06.005).

16. Andre C.M., Ourfir M., Guignard C., Hoffman L., Hausman J.F., Evers D., Larondelle Y. Antioxidant profiling of native Andean potato tubers (Solanum tuberosum L.) reveals cultivars with high levels of beta-carotene, alpha-tocopherol, chlorogenic acid, and petanin. J. Agric. Food Chem., 2007, 55(26): 10839-10849 (doi: 10.1021/jf0726583).

17. Дейнека Л.А. Антоцианы: природные антиоксиданты и не только. Научные ведомости БелГУ. Серия: Медицина и фармация, 2006, 3(4): 92-100.

18. Andersen Ø.M., Jordheim M. The anthocyanins. In: Flavonoids: chemistry, biochemistry and applications /Ø.M. Andersen, K.R. Markham (eds.). London, CRC Press. 2006: 471-552.

19. Eichhorn S., Winterhalter P. Anthocyanins from pigmented potato (Solanum tuberosum L.) varieties. Food Research International, 2005, 38(8-9): 943-948 (doi: 10.1016/j.foodres.2005.03.011).

20. Lewis C.E., Walker J.R.L., Lancaster J.E., Sutton K.H. Determination of anthocyanins, flavonoids and phenolic acids in coloured potatoes. I: Coloured cultivars of Solanum tuberosum L. J. Sci. Food Agric., 1998, 77(1): 45-57 (doi: 10.1002/(SICI)1097-0010(199805)77:1<45::AIDJSFA1 $>3.0 . \mathrm{CO} ; 2-\mathrm{S})$.

21. Мелешина О.В., Мелешин А.А. Создание картофеля с повышенной антиоксидантной активностью - перспективное направление в селекции современных сортов. Мат. науч.практ. конф. «Современное состояние и перспективы развития селекции и семеноводства картофеля». М., 2018: 129-139.

22. Ким И.В., Клыков А.Г. Перспективы развития картофелеводства на Дальнем Востоке. Вестник ДВО РАН, 2018, 3: 12-15.

23. Митюшкин А.А., Журавлев А.А., Жарова В.А., Митюшкин А.В., Салюков С.С., Овечкин С.В., Гайзатулин А.С., Симаков Е.А. Эффективный подбор родительских форм в селекции столовых сортов картофеля для здорового питания. Картофелеводство (сб. науч. тр.). Минск, 2018, вып. 26: 57-64.

24. Анисимов Б.В., Еланский С.Н., Зейрук В.Н., Кузнецова М.А., Симаков Е.А., Склярова Н.П., Филипов С.Н., Яшина И.М. Сорта картофеля, возделываемые в России. М., 2013.

25. Dodds K.S., Long D.H. The inheritance of color in diploid potatoes. 1. Types of anthocyanins and their genetic loci. Journ. of Genetics, 1955, 53: 136-149 (doi: 10.1007/BF02981517).

26. Wang H., Race E.J., Shrikhande A.J. Characterization of anthocyanins in grape juices by ion trap liquid chromatography-mass spectrometry. J. Agric. Food Chem., 2003, 51(7): 1839-1844 (doi: 10.1021/jf0260747). 
27. Kalita D., Jayanty S.S. Comparison of polyphenol content and antioxidant capacity of colored potato tubers, pomegranate and blueberries. Journal of Food Processing and Technology, 2014, 5: 358 (doi: 10.4172/2157-7110.1000358).

\title{
1 ІФГБНУ ФНЦ агробиотехнологий Дальнего Востока Поступила в редакцию им. А.К. Чайки, 4 февраля 2020 года
}

692539 Россия, г. Уссурийск, п. Тимирязевский, ул. Воложенина, 30, e-mail: kimira-80@mail.ru $凹$, volkov_dima@inbox.ru, alex.klykov@mail.ru;

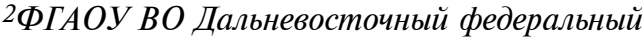

университет,

690091 Россия, г. Владивосток, ул. Суханова, 8,

e-mail: rarf@ya.ru, rarf247@gmail.com, golokhvast.ks@dvfu.ru

Sel'skokhozyaistvennaya biologiya [Agricultural Biology], 2020, V. 55, № 5, pp. 995-1003

\section{COMPOSITION AND QUANTIFICATION OF ANTOCIANS IN HEALTHY-DIET POTATO (Solanum tuberosum L.) VARIETIES FOR GROWING AND SELECTION IN THE RUSSIAN FAR EAST}

\author{
I.V. Kim ${ }^{\boxplus}$, D.I. Volkov'1, V.M. Zakharenko², A.M. Zakharenko'2, K.S. Golohvast ${ }^{2}$, \\ A.G. Klykov ${ }^{1}$
}

${ }^{1}$ Chaika Federal Research Center of Agricultural Biotechnology of the Far East, 30, ul. Volozhenina, pos. Timityazevskii, Ussuryisk, Primorskii Krai, 692539 Russia, e-mail kimira-80@mail.ru ( $\square$ corresponding author), volkov_dima@inbox.ru, alex.klykov@mail.ru;

${ }^{2}$ Far Eastern Federal University, 8, ul. Sukhanova, Vladivostok, 690091 Russia, e-mail rarf@ya.ru, rarf247@gmail.com, golokhvast.ks@dvfu.ru

ORCID:

Kim I.V. orcid.org/0000-0002-0656-0645

Volkov D.I. orcid.org/0000-0002-9364-9225

Zakharenko V.M. orcid.org/0000-0001-5809-6250

The authors declare no conflict of interests

Zakharenko A.M. orcid.org/0000-0002-9520-8271

Golohvast K.S. orcid.org/0000-0002-4873-2281

Acknowledgements:

Supported financially by the Federal Research Program for 2017-2025, Sub-Program "Potato breeding and seed production"

Received February 4, 2020

doi: 10.15389/agrobiology.2020.5.995eng

\section{Abstract}

The potato (Solanum tuberosum L.) has been the focus of dietary research in recent decades due to its ability to accumulate phenolic substances (anthocyanins) in tubers. In Russia, such varieties have been created for a number of regions, but in the Far East, the program to increase the content of anthocyanins in potato tubers has recently begun. In the presented study using liquid chromatography and second-order mass spectrometry methods, we profiled anthocyanins and quantified their accumulation for potato varieties of different origin (Russia, Ukraine, Belarus, Kazakhstan, Germany, the Netherlands), which had not previously been characterized by this feature. For the first time, four dietary Russian varieties with an increased content of anthocyanins have been identified. This work aimed to determine the profiles of anthocyanins and their content in tubers in the conditions of the Russian Far East. We used 22 varieties selected for early maturity, productivity, low starch content and different color of tubers and flowers. The anthocyanin profile was double-identified, by the retention time on a C18 reverse phase column with detection of absorbance at wavelength range 400-700 nm and ESI-MS/MS in positive ionization mode. Anthocyanins were quantified spectrophotometrically. The anthocyanins identified in the tubers were delphinidin, petunidin, malvidin, cyanidin, and pelargonidin. Delphinidin and cyanidin were found in mono- and diglycosylated forms. It was revealed that petunidin-3-glucoside is the most common anthocyanin which is present in almost all of the studied varieties. In tubers, depending on varietal specificity, there were from 1 to 5 anthocyanins of those found. Varieties with yellow skin and pink spots on the yellow tuber skin were characterized by a low content of anthocyanins. The pink and dark pink color of the skin positively correlates with the content of pelargonidin-3-glucoside, while petunidin-3-glucoside and cyanidin-3-glucoside give a purple and blue-violet color to the skin of the tuber. The anthocyanin level was the highest in Phioletovii variety (310 mg/kg cyanidin-3-glucoside, $50 \mathrm{mg} / \mathrm{kg}$ malvidin, $30 \mathrm{mg} / \mathrm{kg}$ delphinidin), Vasilyok variety $(150 \mathrm{mg} / \mathrm{kg}$ petunidin), and in Mayak $(95 \mathrm{mg} / \mathrm{kg}$ pelargonidin) and Kuznechanka $(78 \mathrm{mg} / \mathrm{kg}$ pelargonidin) varieties. In the Phioletovii variety, the cyanidin-3-glucoside prevailed. We recommend to involve varieties with pink, dark pink, purple and blue-purple tuber skin in selection for an increased content of anthocyanins.

Keywords: Solanum tuberosum L., potatoes, dietary varieties, anthocyanins, delphinidin, petunidin, malvidin, cyanidin, pelargonidin, mass spectrometry, HPLC. 